\title{
Mirror therapy for upper limb rehabilitation in chronic patients after stroke
}

\author{
Terapia do espelho no membro superior de \\ pacientes após acidente vascular cerebral
}

\section{Dreyzialle Vila Nova Mota, André Luís Ferreira de Meireles, Marcelo Tavares Viana, Rita de Cássia de Albuquerque Almeida*}

Faculdade Associação Caruaruense de Ensino Superior (ASCES), Caruaru, PE, Brazil

\begin{abstract}
Introduction: Individuals with stroke sequelae present changes in the postural alignment and muscle strength associated with hemiplegia or hemiparesis. Mirror therapy is a technique that aims to improve the motor function of the paretic limb. Objective: The aim of this study was to evaluate the effect of mirror therapy, associated with conventional physiotherapy, for range of motion (ROM), degree of spasticity of the affected upper limb, and the level of independence in the activities of daily living (ADL) of chronic patients after stroke. Methods: This was a quasi-experimental (before and after) study. The study included ten stroke survivors undertaking physiotherapy and presenting with upper limb paresis. The following gauges were used for the present study: goniometry, the Modified Ashworth Scale, Fugl-Meyer and Barthel Index. Fifteen sessions were performed, each lasting 30 minutes, consisting of stretching of the flexor and extensor muscles of the wrist and elbow, pronators and supinators, followed by mirror therapy with gradual functional exercises. Results: Improvement was observed in all aspects studied, however with significant differences for ROM wrist extension $(p=0.04)$
\end{abstract}

"DVNM: Undergraduate Student, e-mail: dreyzi5@hotmail.com

ALFM: Undergraduate Student, e-mail: meireles.andre@hotmail.com

MTV: PhD, e-mail: mtviana0@hotmail.com

RCAA: MSc, e-mail: albuquerquealmeida@gmail.com 
and forearm supination ( $p=0.03$ ). Conclusion: It can be concluded that mirror therapy contributed to the participants' good performance in the aspects studied, mainly in relation to ROM of the affected upper limb.

Keywords:Stroke. Physiotherapy. Hemiplegia. Mirror Neurons.

\section{Resumo}

Introdução: Indivíduos com sequelas de acidente vascular encefálico (AVE) apresentam alterações no alinhamento postural e força muscular associada a uma hemiplegia ou hemiparesia. A terapia de espelho é uma técnica que visa melhorar a função motora do membro parético. Objetivo: O objetivo deste estudo foi avaliar o efeito da terapia do espelho, associada à fisioterapia convencional, na amplitude de movimento (ADM), grau de espasticidade do membro superior acometido e no nível de independência das Atividades de Vida Diária (AVD) de paciente pós Acidente Vascular Cerebral (AVC). Métodos: Trata-se de um estudo quase experimental do tipo antes e depois. Participaram do estudo 10 pacientes pós AVC, os quais se encontrassem em atendimento fisioterapêutico e apresentassem paresia em membro superior. Para a avaliação utilizou-se goniometria, escala de Ashworth modificada, Fugl-Meyer e Índice de Barthel. Foram realizadas 15 sessões com duração de 30 minutos, compostas de alongamento dos músculos flexores e extensores de punho e cotovelo, pronadores e supinadores, seguidos da terapia do espelho com exercícios funcionais gradativos. Resultados: Observou-se melhora em todos os aspectos estudados, porém com diferenças estatisticamente significantes para ADM de extensão de punho $(p=0,04)$ e supinação de antebraço $(p=0,03)$. Conclusão: Pode-se concluir que a terapia do espelho contribuiu para que os participantes desta pesquisa obtivessem boa evolução nos aspectos estudados, principalmente em relação à ADM do membro superior acometido.

Palavras-chave: Acidente Vascular Cerebral. Fisioterapia. Hemiplegia. Neurônios-espelho.

\section{Introduction}

The term stroke is used to define a neurological, transient or permanent deficit in a cerebral area, secondary to vascular injury, of an ischemic or hemorrhagic etiology $(1,2)$.

In the early stages after a stroke, cerebral edema is verified, along with the consequent impairment of the cortico-spinal pathway, which is responsible for the transmission of motor commands. The patient will present involvement of the hemisphere contralateral to the brain injury, which, at this stage, is evidenced by flaccid paralysis of the upper and/or lower limb. The absence of moving will provide to the brain a negative visual feedback which generates a form of paralysis learned (3 - 5).

Stroke is currently considered to be a public health problem, having a high incidence, and being one of the major causes of chronic disability in the world, and the most significant health problem in Latin America (6).
Patient recovery after this kind of injury is related to neural plasticity. A specific task of motor learning can be an important stimulus to promote neuroplasticity and to correct pathological patterns after stroke (4, 7 - 9).

Mirror therapy, or visual mirror feedback, is a noninvasive technique that aims to improve the motor function of the affected limb $(10,11)$. It consists of performing movements with the healthy limb in front of a mirror that is positioned at the body's midline. The patient visualizes the "false" movement of the affected limb. It was first described by Ramachandran and Rogers, in 1996, for the reduction of phantom limb pain in amputees (12). Years later, in 1999, Altschuler and colleagues conducted a pilot study, with the same technique, to stimulate the movements of the hemiparetic limb of patients after stroke $(5,13)$.

The movements of the healthy limb reflected in the mirror transmit the perception that the affected limb is moving, thus generating a positive 
visual feedback that competes against the negative visual feedback generated at the time of clinical onset of the stroke (3). The mirror neurons are recruited in this therapy. These neurons, located in both the frontal and in the parietal lobes, involve interactions between multiple modalities (vision, motor commands and proprioception), and are triggered when there occurs the performance of simple, skillful movements, or when one observes someone else performing the same movement (3, $5,14)$. The movements of the unaffected limb change the excitability of the ipsilateral motor cortex, and benefit the function of the affected limb. According to Lameira et al. (15), the mirror neurons are involved with the tasks of posture and hand laterality, triggering movement.

Considering the lack of studies on this subject, this study aimed to evaluate the effect of mirror therapy as an additional treatment to conventional therapy, functional mobility, degree of spasticity of the affected upper limb, and the level of independence of the activities of daily living (ADL) after stroke.

\section{Material and methods}

This research is a quasi-experimental study, of the before and after type. All patients with neuromotor sequelae resulting from stroke, receiving care at the Clinical School of Physiotherapy, ASCES Faculty, and in the Service Provider Unit (UPS) - Casa Henrique, from February to September of 2012, were selected to participate in the study.

The study included patients with some type of limitation in functional abilities and active range of motion of the wrist and elbow. Patients with a wrist or elbow deformity that restricted the possibility of functional improvements were excluded, as well as those with other associated neurological injuries or illnesses that limited joint mobility, or patients who presented cognitive or visual impairments that prevented the understanding of the commands and their cooperation with those commands.

All patients signed the terms of free and informed consent, according to Resolution 196/96 of the National Health Council (NHC). This study was approved by the Research Ethics Committee of the ASCES Faculty, with protocol number (140/11).
The participants were previously assessed for their range of motion (ROM) for flexion and extension of the wrist and elbow, and pronation-supination of the forearm, using the Carci ${ }^{\circledR}$ brand goniometer (16); the modified Ashworth scale was used to evaluate the extent of spasticity (17); the functionality of the affected upper limb was assessed using the Fulg-Meyer scale $(18,19)$; and, the level of independence in ADL was evaluated using the Barthel index (20). The patients were reassessed after 15 intervention sessions.

The intervention consisted of muscle stretching and mirror therapy. The stretches were performed at the beginning of each session, in the flexor and extensor muscles of the wrist and elbow, and pronators and supinators of the forearm of the healthy and paretic upper limb, in two sets of 30 seconds each (21). Then, mirror therapy was performed to the healthy upper limb, which was made up of graduated functional exercises, according to their complexity. The exercise protocol was based on exercises found in the literature, aiming for the functionality of the activities $(14,22)$, and can be seen in Table 1 .

Table 1 - Graduated Functional Activities

(To be continued)

\begin{tabular}{|c|c|}
\hline 2 sessions & $\begin{array}{c}\text { Opening/closing hand }(3 \times 15) \\
\text { Opposed }(3 \times 15)\end{array}$ \\
\hline 3 sessions & $\begin{array}{c}\text { Movements of active ROM: Flexion-extension of } \\
\text { wrist; elbow pronation-supination with an open } \\
\text { hand ( } 2 \times 10) \\
\text { Handling large objects: ball: pushing and } \\
\text { bringing the ball along the table ( } 2 \times 10) \text {, circular } \\
\text { movements (clockwise and counterclockwise for } \\
1 \text { minute) } \\
\text { Transfer objects - ten objects } \\
\text { Opening/closing the box ( } 2 \times 10) \\
\text { Crushing paper }\end{array}$ \\
\hline 3 sessions & $\begin{array}{l}\text { Fitting: using colored object and forms (remove } \\
\text { and replace } 3 \mathrm{x} \text { ) } \\
\text { Assembling a tower of cups: } 10 \text { cups ( } 3 \mathrm{x}) \\
\text { Kneading of modeling clay } \\
\text { Functional activities: panel (the panel contains: } \\
\text { lock and key, bolt, switches and door locks) }(2 \mathrm{x}) \\
\text { Bringing objects to the mouth (2x10) }\end{array}$ \\
\hline 3 sessions & $\begin{array}{c}\text { Combing hair (2x10) } \\
\text { Using scissors (10x) } \\
\text { Flipping through magazine (10x back and forth, } \\
\text { ten pages) } \\
\text { Handling cards ( } 2 \text { min) } \\
\text { Moving spoon ( } 2 \times 10 \text { clockwise and } \\
\text { counterclockwise ) } \\
\text { Clearing the table ( } 2 \text { min) }\end{array}$ \\
\hline
\end{tabular}




\begin{tabular}{c|c} 
(Conclusion) \\
\hline sessions & $\begin{array}{c}\text { Drawing shapes (circle, triangle, square) }(3 \mathrm{x} \\
\text { each) }\end{array}$ \\
Threading the needle \\
Engagement with rods (20 times) \\
Separating glass beads by color (three colors, \\
ten each)
\end{tabular}

The evaluations and interventions proposed were performed by Researcher A, and the reassessment by Researcher B, who did not have access to the data previously obtained.

For analysis purposes, a probability distribution was performed (percentage analysis). Subsequently, the normal distribution and homogeneity of variance techniques were applied using Shapiro Wilks and Bartlett testing, respectively. The non-parametric Wilcoxon test was used. Data were expressed as median and standard error, with a significance level of $p<0.05$. The Statistical Package for the Social Sciences (SPSS), version 17 for Windows 2010, was used.

\section{Results}

As shown in Figure 1, 28 patients eligible to participate in the study were selected.

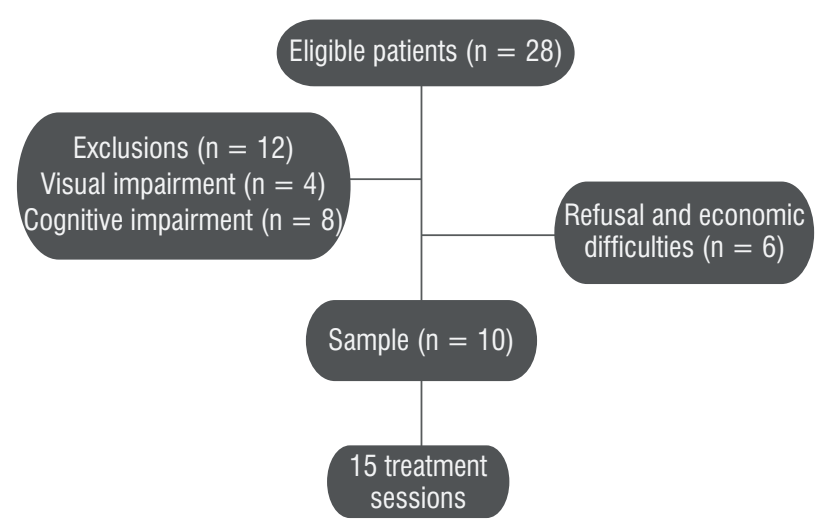

Figure 1 - Flowchart of the study

The mean age of participants was $47 \pm 15$ years; $70 \%$ of the sample was male; the injury time was 34.6 \pm 28.2 months and the physiotherapy performance time prior to the evaluation date was $16 \pm 8$ months.

Table 2 shows the results related to the ROM.

Table 2 - Comparison between range of motion values before and after the intervention (mean and standard error)

\begin{tabular}{lccc}
\hline \multicolumn{1}{c}{ ROM } & $\begin{array}{c}\text { Med - SE } \\
\text { Before }\end{array}$ & $\begin{array}{c}\text { Med - SE } \\
\text { After }\end{array}$ & $\begin{array}{c}\text { Value } \\
\text { of } \mathbf{p}\end{array}$ \\
\hline $\begin{array}{l}\text { Flexion of } \\
\text { wrist }\end{array}$ & $40-9.35$ & $48-10.1$ & 0.4 \\
$\begin{array}{l}\text { Extension } \\
\text { of wrist }\end{array}$ & $25-5.4$ & $32.5-7.9$ & $0.04^{*}$ \\
$\begin{array}{l}\text { Flexion of } \\
\text { elbow }\end{array}$ & $127.5-17.9$ & $130-18.2$ & 0.33 \\
$\begin{array}{l}\text { Extension } \\
\text { of elbow }\end{array}$ & $0-1.7$ & $0-0.6$ & 0.18 \\
$\begin{array}{l}\text { Pronation } \\
\text { Supination }\end{array}$ & $80-12.6$ & $89-11.7$ & 0.18 \\
\hline
\end{tabular}

Note $=$ range of motion, Med $=$ Median, SE $=$ Standard error, Wilcoxon test; * statistically significant difference; $(p<0.05),(n=10)$

The results of the dimension functionality of the upper limb using the Fulg-Meyer scale, before and after the intervention, are shown in Table 3.

Table 3 - Comparison of the Fugl-Meyer values - motor function of upper limb - before and after the intervention (mean and standard error)

\begin{tabular}{cccc}
$\begin{array}{c}\text { Fugl- } \\
\text { Meyer }\end{array}$ & $\begin{array}{c}\text { Med-SE } \\
\text { Before }\end{array}$ & $\begin{array}{c}\text { Med - SE } \\
\text { After }\end{array}$ & Value of $\mathbf{p}$ \\
\hline & $49-5.6$ & $53.5-5.3$ & 0.08 \\
\hline
\end{tabular}

Note $=$ Median, $\mathrm{Se}=$ Standard Error, Wilcoxon Test; $(\mathrm{n}=10)$

As for spasticity, no statistically significant differences before and after the intervention proposal were identified. The Barthel index scores are shown in Table 4.

Table 4 - Comparison between the values of Barthel index - before and after intervention (To be continued)

\begin{tabular}{lccc}
\hline & Score & Before (n) & After (n) \\
\hline $\begin{array}{l}\text { Total } \\
\text { dependence }\end{array}$ & $<25 p$ & 1 & 1 \\
$\begin{array}{l}\text { Severe } \\
\text { dependence }\end{array}$ & $26-50 p$ & 0 & 0 \\
$\begin{array}{l}\text { Moderate } \\
\text { dependence }\end{array}$ & $51-75 p$ & 2 & 2 \\
\hline
\end{tabular}


Table 4 - Comparison between the values of Barthel index - before and after intervention

\begin{tabular}{lccc}
\hline & Score & Before (n) & After (n) \\
\hline $\begin{array}{l}\text { Slight } \\
\text { dependence }\end{array}$ & $76-99 p$ & 6 & 6 \\
Independent & $100 p$ & 1 & 1 \\
\hline
\end{tabular}

\section{Discussion}

An increase in ROM for most analyzed movements was observed after the intervention; however, only the wrist extension and forearm supination movements showed considerable significance.

Mirror therapy has been studied in various aspects of rehabilitation in patients after a stroke, especially in relation to the recovery of ROM of affected limbs. In 2003, Stevens and Stoykov (22) reported an improvement in active ROM of flexion/extension of wrist and pronation/supination of the forearm using this technique in patients after stroke. Cristina et al. (23), in a randomized clinical trial, also obtained similar data on ROM and upper limb function in patients after stroke.

An increase in upper limb functionality affected after the intervention was identified in this study using the Fulg-Meyer scale, but without statistical significance. Similar results using the same scale were identified in the study by Steves and Stoykov (22). Yun et al. (24), and Cristina et al. (23), also applied the Fulg-Meyer scale, and found that the group which performed only the mirror therapy obtained a functional improvement.

Souza, Rangel and Silva (25), verified improvement in functional independence in activities of daily living (ADL) and also in motor function through a case study with six patients, who performed ten sessions with mirror therapy.

We believe that the fact that these patients were already classified as chronic, due to time of injury, may also have influenced the functional response obtained in this study, as well as the small sample size due to losses by refusal; however, we believe that despite not achieving statistical significance, the results were positive and clinically important.

Regarding spasticity, no improvement was found with implementation of this technique, and these results corroborate other literature. Similar results were found in the study of Yavuzer et al. (26), in a randomized clinical trial with 40 patients, in which upper limb mirror therapy was applied to a group of patients after stroke. Later, corroborating the above-mentioned result, Yun et al. (24), using a quasi-experimental study with 60 patients divided into three groups (electrostimulation; mirror therapy + electrostimulation; mirror therapy), did not observe differences related to spasticity in the three groups.

The ineffectiveness of the technique on spasticity can be attributed to the fact that mirror therapy does not act directly on the muscle spindles, which is fundamental for its reduction by slowing the nervous signaling transmission. The treatments classically recommended for reducing spasticity, such as strengthening of the antagonist muscle, cryotherapy and botulinum toxin application, act directly on the muscle spindle, decreasing excitability (27 - 29).

In relation to the ADL, as measured by the Barthel index, patients showed improvement in the individual score, but the improvement was not enough to provide change in the functional category, given that the Barthel index results are interpreted in categories ranging from total dependence to independence of the patient. Franceschini et al. (11), using a quasiexperimental study with 28 patients, observed significant differences in the ADL. Later, Ietswaart et al. (30), in a clinical trial using three groups (mirror therapy, placebo, conventional physiotherapy), concluded that the group that received intervention with mirror therapy achieved more significant gains than the others. It is noteworthy that, in this study, $60 \%$ of the sample already had a slight degree of dependence, considered a good level of independence, and, therefore, a determining factor for absence of change of category in the scale.

\section{Conclusion}

Stroke is a clinical syndrome in which the patient may progress toward extensive motor impairment, such as spasticity, muscle shortening, fatigue, biomechanical and functional changes, and, consequently, a decreased quality of life. Thus, performance of physiotherapy and the inclusion of new techniques in clinical practice that may help with motor rehabilitation of these patients, become increasingly important.

The recovery of the ROM and upper limb function is a major concern during the patient's rehabilitation after stroke. Of the $80 \%$ of the patients with acute 
upper limb paresis after stroke, only one third achieve full functional recovery.

The use of mirror therapy for the recovery of patients after stroke is recent, and there are few controlled studies with representative sample numbers.

According to the results obtained in this study, it can be concluded that the mirror therapy, in combination with conventional physiotherapy, contributed to the good performance of the volunteers participating in this research, especially in relation to the recovery of ROM of the affected upper limb. Given these results, it is believed that increasing the sample size would provide better results in the remaining aspects studied. More studies with larger numbers of participants, and controlled group training must be conducted to prove the effectiveness this technique.

\section{References}

1. Radanovic M. Características do atendimento de pacientes com acidente vascular cerebral em hospital secundário. Arq Neuro-Psiquiatr. 2000; 58(1):99-106.

2. Remesso GC, Fukujima MM, Chiappetta ALML, Oda AL, Aguiar AS, Oliveira ASB , et al. Swallowing disorders after ischemic stroke. Arq Neuro-Psiquiatr. 2011; 69(5):785-9.

3. Machado S, Velasques B, Paes F, Cunha M, Basile LF, Budde $\mathrm{H}$. et al. Terapia-espelho aplicada à recuperação funcional de pacientes Pós-Acidente Vascular Cerebral. Rev Neurocienc. 2011;19(1):171-75.

4. Stokes M. Neurologia para Fisioterapeutas. São Paulo: Editorial Premier, 2000.

5. Ramachandran VS, Altschuler EL. The use of visual feedback, in particular mirror visual feedback, in restoring brain function. Brain, 2009; 132:1693-1710.

6. Faria CDCM, Silva SM, Corrêa JCF, Laurentino GEC, Texeira-Salmela LF. Identificação das categorias de participação da CIF em instrumentos de qualidade de vida utilizados em indivíduos acometidos pelo acidente vascular encefálico. Rev Panam Salud Publica. 2012; 31(4):338-44.
7. Fernandes CIS. Reaprendizagem Motora e Fisioterapia Neurológica - Revisão Bibliográfica [Dissertação]. Porto: Universidade Fernando Pessoa; 2012.

8. Moura EW, Lima E, Borges D, Silva PAC . Fisioterapia: Aspectos Clínicos e Práticos da Reabilitação. 2.ed. São Paulo: Artes Médicas, 2010.

9. Borella MP, Sacchelli T. Os efeitos da prática de atividades motoras sobre a neuroplasticidade. Rev Neurocienc. $2009 ; 17(2): 161-9$.

10. Steves JA, Stoykov MEP. Simulation of Bilateral Movement Training Through Mirror Reflection: A Case Report Demonstrating an Occupational Therapy Technique for Hemiparesis. Top Stroke Rehabil. 2004; 11(1):59-66.

11. Franceschini M, Agosti M, Cantagallo A, Sale P, Mancuso M, Buccino G. Mirror Neurons : action observation treatment as a tool in stroke rehabilitation. Eur J Phys Rehabil Med. 2010; 46(4):517-23.

12. Ramachandran VS, Rogers-Ramachandran D. Synaesthesia in phanthom limbs induced with mirrors. Proc R Soc Lond B. 1996; 263:377-86.

13. Altschuler EL, Wisdoma SB, Stonea L, Fostera C, Galaskoa D, Llewellyna DME, et al. Rehabilitation of hemiparesis after stroke with a mirror. Lancet. 1999; 353(9169): 2035-36.

14. Deconinck FJA, Smorenburg AR, Benham A, Ledebt A, Feltham MG, Savelsbergh G J. Reflections on Mirror Therapy: A Systematic Review of the Effect of Mirror Visual Feedback on the Brain. Neurorehabilitation Neural Repair. 2015; 29(4):349-61.

15. Lameira AP, Gawryszewski LG, Pereira Junior A. Neurônios Espelho. Psicol USP. 2006; 17(4):123 - 33.

16. Silva SS, Fonseca EATS, Souza HRR, Mendes EC, Carvalho RW. Análise do comportamento cinemático da marcha de um indivíduo submetido a artroplastia total de quadril. Fisioter Bras. 2005; 6(3):230-33.

17. Minutoli VP; Delfino M; Freitas STTF; Lima MO; Tortoza C; Santos CA. Efeito do movimento passivo contínuo isocinético na hemiplegia espástica. Acta Fisiatr. 2007;14(3):142-48. 
18. Carvalho TB, Relvas PCA, Rosa SF. Instrumentos de avaliação da função motora para indivíduos com lesão encefálica adquirida. Rev Neurocienc. 2008; 16(2):137 - 43.

19. Maki T, Quagliato EMAB, Cacho EWA, Paz LPS, Nascimento NH, Inoue MMEA, et al. Estudo de confiabilidade da aplicação da escala de Fugl-meyer no Brasil. Revista Bras Fisioter. 2006; 10(2):177 - 83.

20. Caneda MAG, Fernandes JG, Almeida AG, Mugnol FE. Confiabilidade de escalas de comprometimento neurológico em pacientes com Acidente Vascular Cerebral. Arq Neuropsiquiatr. 2006; 64(3-A):690-97.

21. Almeida TT, Jabur NM. Mitos e verdades sobre flexibilidade: reflexões sobre o treinamento de flexibilidade na saúde dos seres humanos. Motricidade. 2007; 3(1):337-44.

22. Stevens JA, Stoykov MEP. Using Motor Imagery in the Rehabilitation of Hemiparesis. Arch Phys Med Rehabil. 2003; 84:1090 - 2.

23. Cristina LM, Matei D, Ignat B, Popescu CD. Mirror therapy enhances upper extremity motor recovery in stroke patients. Acta Neurol Belg. 2015; 115(4):597-603.

24. Yun GJ, Chun MH, Park JY, Kim BR. The Synergic Effects of Mirror Therapy and Neuromuscular Electrical Stimulation for Hand Function in Stroke Patients. Ann Rehabil Med. 2011; 35(3): 316-21.

25. Souza WC, Rangel MCM, Silva EB. Mirror Visual Feedback na Recuperação Motora e Funcional da Mão Após Acidente Vascular Cerebral. Rev Neurocienc. 2012; 20(2):254-59.
26. Yavuzer G, Selles R, Sezer N, Sütbeyaz S, Bussmann JB, Köseoglu F, Atay MB, Stam HJ. Mirror Therapy Improves Hand Function in Subacute Stroke: A Randomized Controlled Trial. Arch Phys Med Rehabil. 2008; 89(3):393 - 8.

27. Junqueira RT, Ribeiro AMB, Scianni AA. Efeitos Do Fortalecimento Muscular e sua Relação com a Atividade Funcional a a Espasticidade em Indivíduos Hemiparéticos. Rev Bras Fisioter. 2004; 8(3):247-52.

28. Felice TD, Santana LR. Recursos Fisioterapêuticos (Crioterapia e Termoterapia) na espasticidade: revisão de literatura. Rev Neurocienc. 2008; 17(1)57-62.

29. Segura DCA, Adamchuk CC, Nascimento FC, Moraes NV. A utilização da toxina botulínica associada à fisioterapia para o controle da espasticidade. Arq Ciênc Saúde. 2005; 9(3):217-22.

30. Ietswaart M, Johnston M, Dijkerman HC, Joice S, Scott CL, MacWalter SL. Mental practice with motor imagery in stroke recovery: randomized controlled trial of efficacy. Brain. 2011; 134(5): 1373-86.

Received: 06/20/2013

Recebido: 20/06/2013

Approved: 08/19/2015

Aprovado: $19 / 08 / 2015$ 
